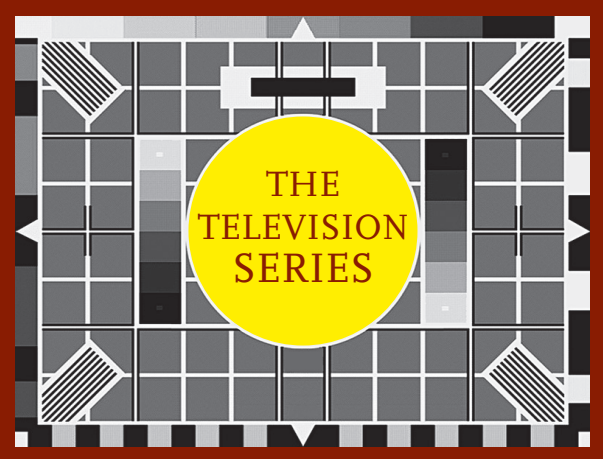

Jimmy
McGovern

STEVE BLANDFORD 


\section{THE \\ TELEVISION SERIES}

\section{Jimmy McGovern}

\section{MANCHESTER 1824}

Manchester University Press 


\title{
THE TELEVISION SERIES
}

\author{
series editors \\ JONATHAN BIGNELL \\ STEVEN PEACOCK \\ former editor \\ SARAH CARDWELL \\ already published
}

Alan Bennett KARA MCKECHNIE

Alan Clarke DAVE ROLINSON

Andrew Davies SARAH CARDWELL

Tony Garnett STEPHEN LACY

Trevor Griffiths JOHN TULLOCH

Troy Kennedy Martin LEZ COOKE

Terry Nation JONATHAN BIGNELL AND ANDREW O'DAY

Jimmy Perry and David Croft SIMON MORGAN-RUSSELL

Lynda La Plante JUlia HALlam

Jack Rosenthal SUE VICE 


\section{STEVE BLANDFORD}

\section{Jimmy McGovern}

\section{Manchester University Press}

MANCHESTER AND NEW YORK

distributed in the United States exclusively by Palgrave Macmillan 
Copyright (C) Steve Blandford 2013

The right of Steve Blandford to be identified as the author of this work has been asserted by him in accordance with the Copyright, Designs and Patents Act 1988.

Published by Manchester University Press

Oxford Road, Manchester M13 9NR, UK

and Room 400, 175 Fifth Avenue, New York, NY 10010, USA

www.manchesteruniversitypress.co.uk

Distributed in the United States exclusively by

Palgrave Macmillan, 175 Fifth Avenue, New York, NY 10010, USA

Distributed in Canada exclusively by

UBC Press, University of British Columbia, 2029 West Mall,

Vancouver, BC, Canada v6T 1z2

British Library Cataloguing-in-Publication Data

A catalogue record for this book is available from the British Library

Library of Congress Cataloging-in-Publication Data applied for

ISBN 978 ○ 719082481 hardback

First published 2013

The publisher has no responsibility for the persistence or accuracy of URLs for any external or third-party internet websites referred to in this book, and does not guarantee that any content on such websites is, or will remain, accurate or appropriate.

Typeset in Scala with Meta display by

Koinonia, Manchester

Printed in Great Britain by

The MPG Books Group, Bodmin 